\title{
A Case of Reflex Sympathetic Dystrophy (RSD) Satisfactorily Treated with Uzu-keishi-to
}

\author{
Mosaburo KAINUMA Shoko SENDA Naoki MANTANI \\ Yutaka SHIMADA Katsutoshi TERASAWA
}

Department of Japanese Oriental (Kampo) Medicine, Faculty of Medicine, Toyama Medical and Pharmaceutical University, 2630 Sugitani, Toyama 930-0194, Japan

\author{
烏頭桂枝湯が奏効した反射性交感神経性 \\ ジストロフィーの 1 例 \\ 貝沼茂三郎 仙田晶子 萬谷 直樹* \\ 嶋田 豊 寺澤 捷年 \\ 富山医科薬科大学医学部和漢診療学講座, 富山, † $930-0194$ 富山市杉谷2630
}

\begin{abstract}
'We encountered a patient with chronic pain due to reflex sympathetic dystrophy (RSD) that was relieved by Uzu-keishi-to (Wu tou gui zhi tang) therapy. A 69-year-old man was diagnosed with RSD in 1995. Intractable pain of the extremities and trunk persisted despite several therapies such as spinal cord stimulation, local anesthetic blocks, and a variety of conventional medications. The patient was admitted to our hospital in June 2000, and was diagnosed as having stage II RSD. Thermography demonstrated that the left side of the back and the hand were lower in temperature than the corresponding areas of the right side. "Perfusion" images of threephase bone scintigraphy showed a lower flow in the lower left extremity. Uzu-keishi-to was administered in addition to the Western medicines. After administration of Uzu-keishi-to, the pain was relieved and the value of the face scale decreased from 20 to 11 . Moreover, after 16 weeks of Uzu-keishi-to therapy, the decreased blood flow on the left side of the body detected by thermography and three-phase bone scintigraphy increased to a level equal to that of the right side. Uzu-keishi-to is effective not only in reducing the intractable pain of RSD but also in preventing the development of "dystrophy." Further evaluation of Uzu-keishi-to therapy for patients with RSD is warranted.
\end{abstract}

Key words : reflex sympathetic dystrophy, Uzu-keishi-to, Kampo medicine, thermography, bone scintigraphy

\section{要旨}

反射性交感神経性ジストロフィー（RSD）の慢性疼痛に，烏頭桂枝湯が奏効した 1 例を経験した。患者は69歳男 性で，1995年にRSD と診断され，四肢および体幹の頑固な疼痛は，脊髄電気刺激法，神経ブロックや種々の薬剈 に抵抗して持続した。2000年 6 月当科に入院し，RSDのステージロと診断された。サーモグラフィーでは，左側背 部と左側手部〜手指の温度が右側と比較して低下しているのが確認され，3相性骨シンチグラフィーの血管相でも 左側足部の血流の低下がみとめられた。従来からの西洋薬に加えて烏頭桂枝湯を開始したところ，16週後には疼痛 は半減しフェイススケールも20から11点に減少した。さらに，サーモグラフィーや 3 相性骨シンチグラフィーの血 管相でみられた左側の血流低下も，右側と同程度にまで回復した。烏頭桂枝湯は，RSDの頑固な疼痛に有効である だけでなく, ジストロフィーの進行防止にも有効である可能性が示唆された。RSD 患者における烏頭桂枝湯の有効 性については，さらなる検討が求められる。

キーワード：反射性交感神経性ジストロフィー，烏頭桂枝湯，漢方薬，サーモグラフィー，骨シンチグラフィー

\section{Introduction}

Reflex sympathetic dystrophy (RSD), corresponding to the complex regional pain syndrome (CRPS) type $\mathrm{I}^{1 \text { ), }}$ is a chronic pain state that sometimes occurs after soft tissue or bone injury ${ }^{23)}$. The pain of RSD is accompanied with autonomic changes such as sweating or vasomotor abnormalities $^{3)}$, and progression of RSD finally causes atrophy of skin and bone ${ }^{2 !}$.

Conventional pain medication, physical therapy, sympathetic blocks, and transcutaneus electrical stimulation 
of nerves have all been used to reduce the intensity of pain caused by RSD, but with generally unfavorable results $^{3 / 4)}$. An effective treatment for RSD has not yet been established. In the field of Kampo medicine, Kampo formulae including Uzu (Aconiti-tuber) have been used to treat patients with chronic pain ${ }^{5}$. Here we present a case of refractory RSD satisfactorily treated with Kampo formulae, Uzu-keishi-to（烏頭桂枝湯）.

\section{Case}

In June 2000, a 69-year-old man consulted our department with a complaint of intractable pain due to RSD. At the age of 64 , he fell down stairs and required surgery for cervical bone fracture, the anterior cervical fusion (C 7 Th 1). Post operatively, he developed a pain in the bilateral upper and lower extremities and trunk. The pain, accompanied by allodynia (pain from non-noxious stimulus) of the feet and an incandescent feeling in the trunk, persisted despite treatment with several medications. He was admitted to a university hospital, and diagnosed as

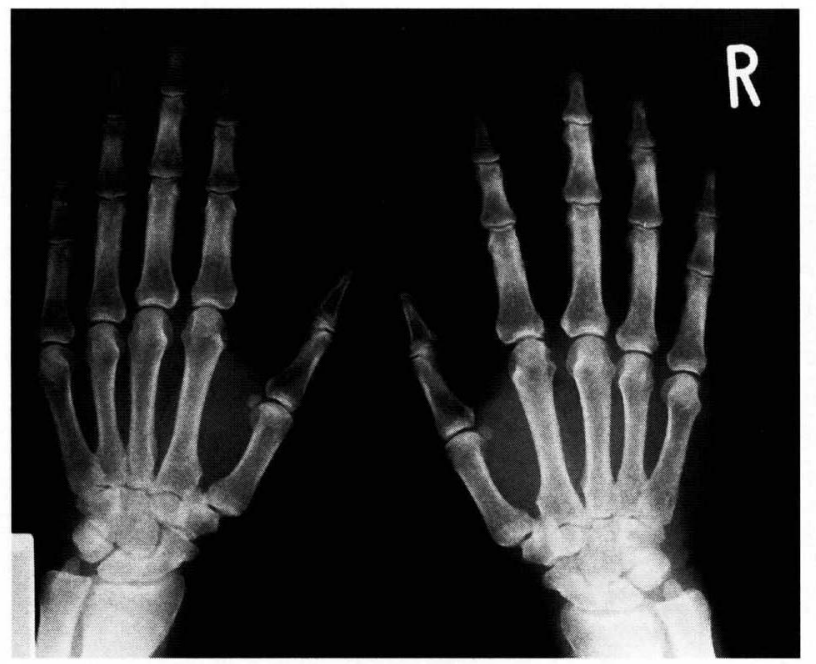

Fig.1 Plain radiograph of both hands, showing osteoporosis, cortical cavitation, and loss of bone substance on the left. having RSD in 1997. Cervical my elopathy or radiculopathy was negated by orthopedists. In that hospitalized period, he was treated by analgesics, anti-depressant, blockade of nerves including sympathetic nerve block, and spinal cord stimulation, with no improvement. After leaving the hospital, the pain had been persisting, despite treatment with many kinds of therapy. Thereafter, the patient consulted our department.

In June 2000, he was admitted to Toyama Medical and Pharmaceutical University hospital. Physical characteristics on admission were as follows : body height $161 \mathrm{~cm}$, body weight $64.6 \mathrm{~kg}$, blood pressure $120 / 80 \mathrm{mmHg}$, and heart rate $80 / \mathrm{min}$. There was no apparent edema of the extremities. The body was extremely moist with sweat. Neurologically, the reflexes of the extremities were diminished, but neither motor weakness nor functional disturbance was observed.

There was no abnormality in the laboratory data except for mild liver disorder and hyperlipidemia. Left-sidedominant bone atrophy in the fingers was found on X-ray films (Fig.1), but there were no spinal canal stenosis finding observed on cervical X-ray. The patient met the diagnostic criteria for RSD established by the International Association for the Study of Pain ${ }^{1)}$, and also met the criteria established by Kemler et $\mathrm{al}^{6)}$. We diagnosed the patient as being at stage 2 described by Lankford ${ }^{7}$. Thermography demonstrated that skin temperature of the left hand and the left back was markedly lower than that of the right side (Fig.2 a, 2 b). Three-phase bone scintigraphy was performed following $\mathrm{N}$ injection of technetium-99 m methylene diphosphonate: in the first phase, rapid sequential images of the lower extremities were acquired every 5 seconds for 60 seconds ("perfusion" images), and static images of the extremities were obtained 2 minutes ("blood pool" images) and 3 hours ("bone" images) after injection ${ }^{8)}$. Although the uptake on bone scintigraphy was symmetric and did not increase on either
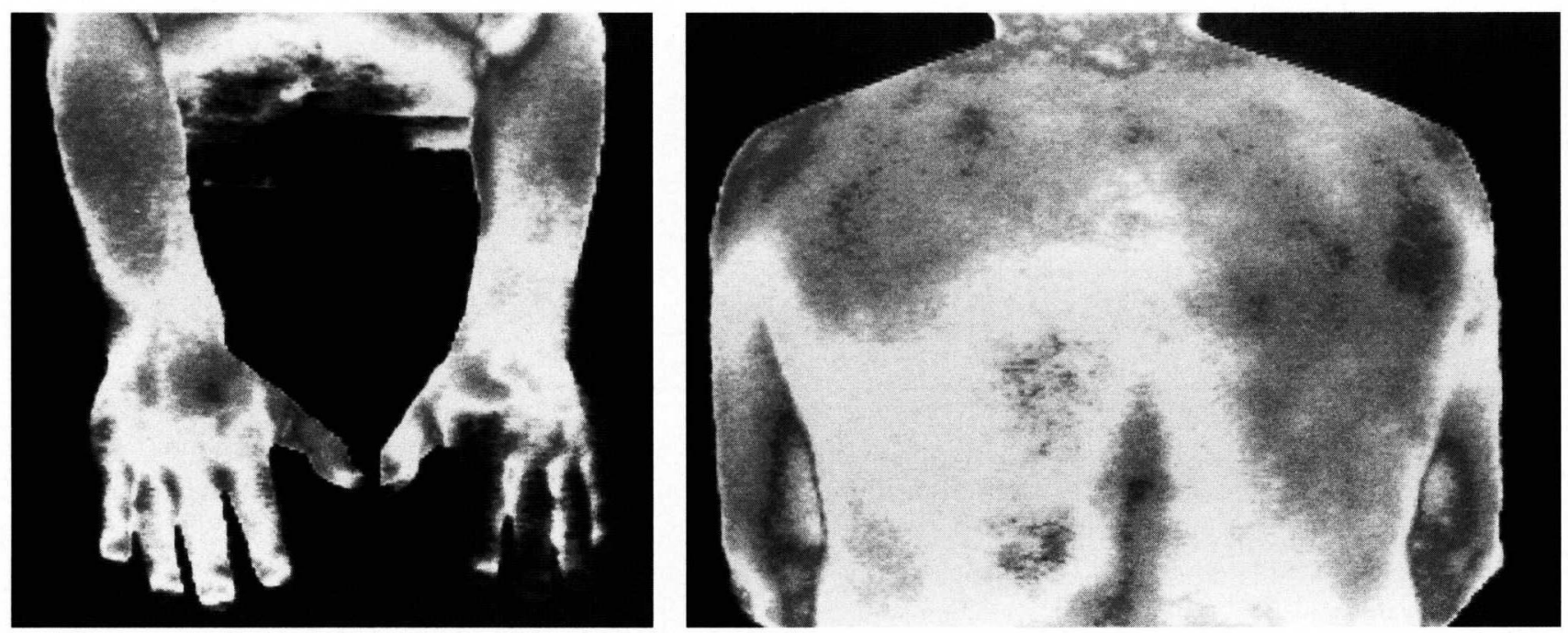

Fig.2 a, 2 b Thermogram, showing lowered skin temperature of left hand (Fig. 2a) and left back (Fig. 2b). 


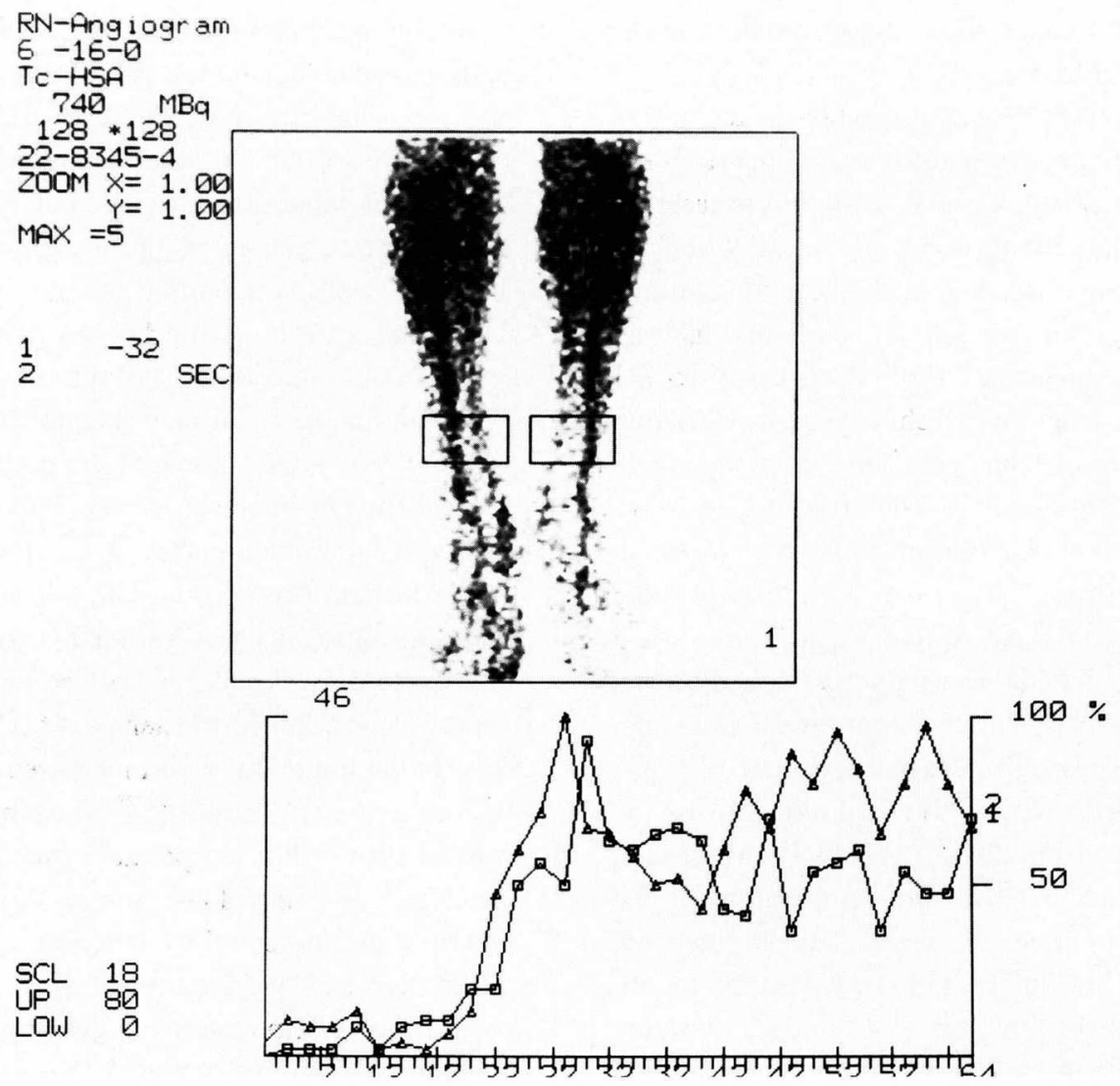

$-13-0$

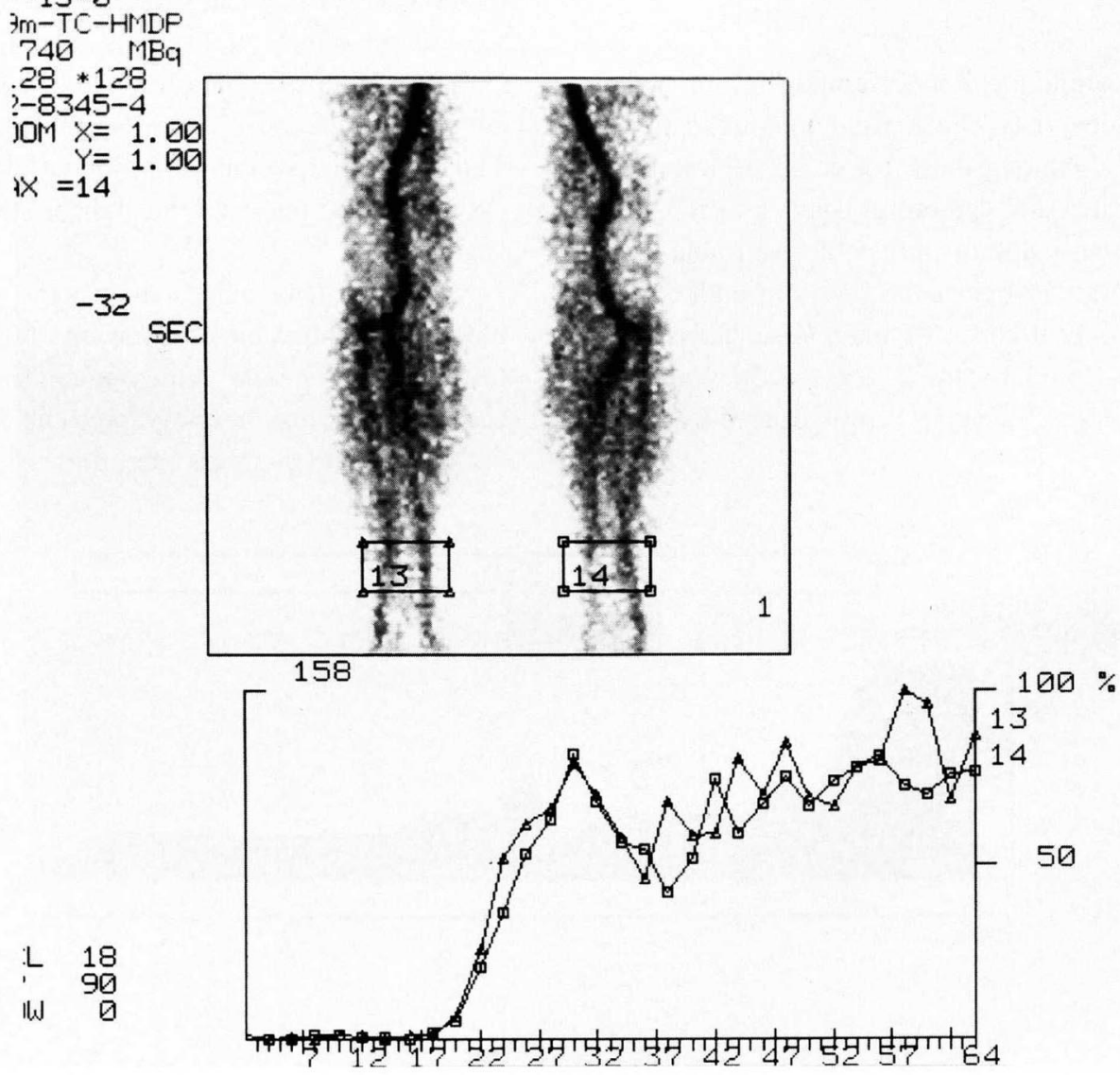

Fig.3 a, 3 b Perfusion Images (3-phase bone scintigram) of the lower extremities. A decreased flow in the left lower extremity on admission (Figure 3 a) recovered after 16 weeks of Uzu-keishi-to therapy (Figure $3 \mathrm{~b}$ ). 
side, the "perfusion" images showed a lower flow in the left lower extremity (Fig.3 a).

The western medicines he was receiving on the day of admission were continued unchanged during the hospitalized period ; $100 \mathrm{mg}$ of amobarbital, $2 \mathrm{mg}$ of clonazepam, $1 \mathrm{mg}$ of etizolam, and $20 \mathrm{mg}$ of imipramine hydrochloride, per day. In addition to these medicines, we administered Uzu-keishi-to (Wu tou gui zhi tang in Chinese) based on Kampo-assessment, "sho" (Uzu-keishi-to has been indicated for symptoms such as excess sweating, sleep disturbed by intractable pain, and cold feeling in the exterior layers of the body ${ }^{5)}$ ). The dose of Uzu (Aconiti tuber), contained in Uzu-keishi-to as a component herb, was started from $2.0 \mathrm{~g}$, and adjusted to $4.5 \mathrm{~g}$ 3 weeks after admission.

The chronic pain of RSD was reduced gradually after administration of Uzu-keishi-to. After the 16-week period of Uzu-keishi-to therapy, the pain evaluated by visual analogue scale decreased to half, and the value on the facescale $^{9)}$ decreased from 20 to 11 (Fig.4). Moreover, thermography showed that the skin temperature of the left hand increased to equal the level of the right hand, and the decreased flow in the left lower extremity observed during the "perfusion" phase of bone scintigraphy recovered after 16 weeks of Uzu-keishi-to therapy (Fig.3 b). Pain relief has persisted to date.

\section{Discussion}

In the field of Kampo medicine, Kampo formulae containing Aconiti Tuber have been used to treat patients with chronic pain ${ }^{5}$. Among these formulae, Uzu-keishito has been indicated for symptoms such as excessive sweating, sleeplessness due to intractable pain, and cold feeling in the exterior layers of the body, in addition to painful conditions. Uzu-keishi-to may have been used since ancient times to treat some patients with sympathicotonia, since excessive sweating can be caused by sympathicotonia.
In the present case, the 5-year-history of persistent pain was relieved and the values of visual analogue scale and face scale decreased to half after administration of Uzu-keishi-to, which contains Aconiti Tuber ("Uzu” or "Bushi" in Japanese) as an herbal component. Pharmacological mechanism of the analgesic effect of Aconiti Tuber as well as aconitine (a main alkaloid of Aconiti Tuber) have been clarified in several experimental studies $^{10) 11)}$. Although we did not attempt to use Aconiti Tuber alone in the traditional manner of Kampo medicine, the analgesic effect shown in the patient may be attributable, at least in a part, to Aconiti Tuber.

Also of particular note in the present case, the decreased blood flow on the left side of the body detected by thermography and 3 phase bone scintigraphy increased to a level equal to that on the right side after 16 weeks of Uzu-keishi-to therapy. It is reported that blood flow in the impaired region increases during stage I RSD, then decreases at stage $\Pi^{12 / 13)}$. Mashimo reported that improvement of skin temperature on thermography sometimes reflects clinical effectiveness in patients with RSD which is accompanied by autonomic dysregulation with vasomotor and sudomotor changes ${ }^{12)}$. Yamaga also reported that thermography in RSD patients is useful to evaluate availability of treatments : a difference in temperature between the impaired side and the intact side of the body was disappeared after effective treatment ${ }^{13)}$. The vasodilator effects of Paeoniae Radix ${ }^{14)}$ and Cinnamomi Cortex ${ }^{15)}$, both of which are herbal components of Uzukeishi-to, have been reported in experimental studies. Thus, the improvement of blood flow in the presented case may have reflected the clinical effectiveness of Uzukeishi-to.

Moreover, it is suggested that the persistence of low blood flow causes the progression of distal tissue atrophy (dystrophy $)^{16) 17}$. The improvement in low blood flow confirmed by the thermography and 3-phase bone scintigraphy would suppress the progression of dystrophy in

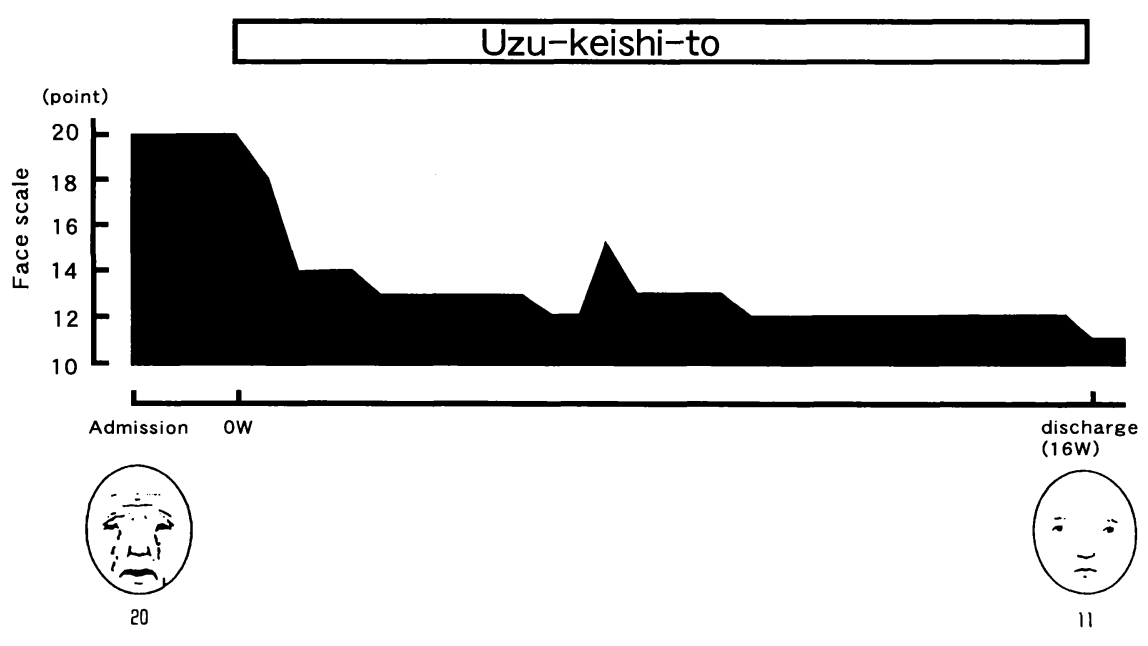

Fig.4 Clinical course 
the patient.

It has been reported that chronic RSD or causalgia was satisfactorily treated with Kampo medicines : Gorei-san ${ }^{187}$, Keishi-ka-ryojutsubu-to ${ }^{19 !}$, and Touki-shigyakuka-goshuyu-shokyo-to ${ }^{20)}$. In those reported cases, thermography or 3 phase bone scintigraphy was not performed after administration of Kampo medicines. We are not aware of any reports that described alleviation of RSD after Uzukeishi-to therapy.

In conclusion, we presented a case of refractory RSD satisfactorily treated with Uzu-keishi-to. After 16 weeks of Uzu-keishi-to therapy, decreased blood flow on the left side of the body detected by the thermography and 3phase bone scintigraphy increased to a level equal to that on the right side. Uzu-keishi-to may be effective not only in reducing the intractable pain of RSD but also in preventing progression to "dystrophy". Uzu-keishi-to therapy might be a useful additional or alternative agent for the treatment of RSD.

\section{Supplementary Notes}

Uzu-keishi-to contains 6 herbs : Cinnamomi Cortex (4 g), Zingiberis Rhizoma ( $1 \mathrm{~g}$ ), Zizyphi Fructus (3 g), Paeoniae Radix (3 g), Glycyrrhizae Radix (2 g), Aconiti Tuber (1-4 g). The 5 herbs except Aconiti Tuber were extracted in boiled water $(600 \mathrm{ml})$ for $40 \mathrm{~min}$, and the extract from 5 herbs was then added to the extract of Aconiti Tuber which was extracted in $40 \mathrm{~g}$ of honey for $90 \mathrm{~min}$.

\section{References}

1) Merskey, H., ed, : International association for the study of pain (IASP) : subcommittee on taxonomy, classification of chronic pain, description of pain terms Pain, 3 (Suppl.) (1986)

2 ) Poplawski, Z.J., Wiley, A.M., Murray, J.F. : Posttraumatic dystrophy of the extremities. J. Bone. Joint. Surg., 65-A, 642-655, 1983.

3 ) Schwartzman,R.J., McLellan, TL. : Reflex sympathetic dystrophy. A review. Arch. Neuro., 44, 555-561 (1987)

4 ) Ochoa, J.L. : Essence, investigation, and management of "neuropathic" pains : hopes from acknowledgment of chaos. Muscle, Nerve., 16, 997-1008 (1993)

5 ) Terasawa, K. : "Kampo (Japanese-Oriental medicine)", K.K.Standard McIntyre, Tokyo (1993)

6 ) Kemler, M.A., Barendse, GAM., van Kleef, M., de Vet, HC., Rijks, CP., Furnee, CA., van den Wildenberg, FA. : Spinal cord stimulation in patients with chronic reflex sympathetic dystrophy. N.Eng.J.Med., 343, 618$624(2000)$

7 ) Lankford, L.L., Thompson, J.E. : Reflex sympathetic dystrophy, upper and lower extremity ; diagnosis and management. AAOS, 26, 163-178 (1977)

8 ) McCarthy, E.F. : Histopathologic correlates of a positive bone scan. Sem. Nucl. Med., 27, 309-320 (1997)

9 ) Lorish, C.D., Maisiak, R. : The face scale : a brief, nonverbal method for assessing patient mood. Arthritis. Rheum., 29, 906-909 (1986)

10) Murayama, M., Hikino, H. : Stimulating actions on ribonucleic acid biosynthesis of aconitines, diterpenic alkaloids of Aconitum roots. J.Ethnopharmacol., 12, 25-33 (1984)

11) Kitagawa, I., Chen, Z.L., Yashihara, M., Kobayashi K., Yoshikawa, M., Ono, N., Yoshimura, Y.: Chemical studies on crude drug processing. III. Aconiti Tuber (2). On the constituents of "Pao-fuzi", the processed Tuber of Aconitum carmichaeli DEBX. and biological activities of Lipo-alkaloids. Yakugaku Zasshi, 104, 858-866 (1984)

12) Mashimo, T. : Pathogenesis of complex regional pain syndrome (CRPS). Nippon Rinsho, 59, 1655-1662 (2001)

13) Yamaga, M., Ushijima,F., Kato,T., Ide,J., Takagi,K. : Treatment of reflex sympathetic dystrophy. Neurol. Med., 54, 306-314 (2001)

14) Goto, H., Shimada, Y., Akechi, Y., Kohta, K., Hattori, M., Terasawa, K. : Endothelium-dependent vasodilator effect of extract prepared from the roots of Paeonia lactiflora on isolated rat aorta. Plant. Med., 62, 436439 (1996)

15) Tanikawa, K., Goto, H., Nakamura, N.,Tanaka,N., Hattori,M., Itho,T., Terasawa,K. : Endothelium-dependent vassodilator effect of tannin extract from Cinnamonomi Cortex on isolated rat aorta. J. Trad. Med., 16, 45-50 (1999)

16) van der Laan L., ter Laak H.J., Gabreels-Festen A., Gabreels F., Goris R.J.A. : Complex regional pain syndrome type I (RSD). Neurology, 51, 20-25 (1998)

17) Janig,W. : Pain and the sympathetic nervous system : pathological mechanisms. In Autonomic failure. A textbook of clinical disorders of the autonomic nervous system. 4 th ed. (edited by Mathias CJ, Bannister R), Oxford Univ. Press, New York 2000, pp 99-108.

18) Tachihara, H., Itoh, T., Suda, T., Hamada, K., Yanagita, K., Abe, Y., Shiraishi,S., Fukutome, T., Yakazu, Y : Facial causalgia developing following to tooth extraction. Pain and Kampo medicine, 4, 43-49 (1994)

19) Watanabe, H., Namiki, A. : A case of reflex sympathetic dystrophy (RSD) (CRPS ; Type 1) with bronchial asthma and atopic dermatitis. Pain and Kampo medicine 8, 41-43 (1998)

20) Nagata, K., Morishita, K., Fujioka, K., Yamazaki, M., Okamoto, A. : A case of completely improved RSD in a ultra-short period. Pain and Kampo medicine, 8, 5357 (1998) 